\title{
Factors Of Student Speech Development In Karakalpak Classes
}

\section{Olimjon Eshimbetov}

\section{Assistant Teacher, Nukus State Pedagogical Institute Named After Ajiniyaz, Uzbekistan}

\author{
G OPEN ACCESS \\ The American Journal of \\ Social Science And \\ Education Innovations \\ JULY 2020 \\ Page No.: 195-198 \\ Volume-II Issue-VII \\ PUBLISHED: 30 JULY 2020 \\ www.usajournalshub.com/inde \\ x.php/tajssei \\ Copyright: Original content \\ from this work may be used \\ under the terms of the \\ Creative Commons Attribution \\ 4.0 licence.
}

\begin{abstract}
This article provides theoretical and practice al recommendations for the development of connected speech of students in grades 2-6 in Karakalpak classes. It deals with didactic games, poetic texts, excursions aimed at enriching the child's imagination.
\end{abstract}

Keywords: speech, communication, imagination, excursion, process, practice, pedagogy, syntax, imagery lyrical digressions, integrity, constructive, dedications.

\section{Introduction}

The development of any society is also determined by the reform of the national language. The development of the national language in close connection with the socio-psychological process often occurs at the expense of the acquired words. Because of the importance of the direct role of the teacher in the education of the child, it is necessary to regularly develop their speech. In Karakalpak classes, the subject "Uzbek language" (State language) is taught not only to students to develop speech, but also to develop their written speech, as well as the formation of their correct pronunciation.

Considering that the Uzbek language is usually taught in the 2nd grade in groups with Karakalpak classes, it seems that a clear solution to the problem has been found. It is the students who tend to receive a lot of information from the world around them at that time. At this time, if the student becomes accustomed to independent thinking, pronounces the names of objects correctly, writes the text correctly, and finds the strength to use the words he hears freely during free communication. 


\section{The Main Findings And Results}

In the education system of Karakalpakstan, the official languages are Karakalpak and Uzbek. If in the Karakalpak classes attention is paid to the Uzbek language, to the mastery of the meanings of the words in it, then the goal will be achieved. This requires the teacher to be active, because at the time of preparation for each lesson, the teacher should work on the basis of the program plan, taking into account the age and class. For example, in what form are these done: first, the teacher organizes the topic according to a clear and thorough plan; second, to re-examine the reliability of the sources on the subject; third, the emergence of difficult-to-pronounce words on the subject in the form of games and demonstrations; fourth, they will have to compile and use thematic dictionaries on the topic.

Research on speech activity states: "Well-developed speech is one of the most important means of active participation in society, and for the student, speech is a means of successful learning in school. The child should be taught to speak fluently from an early age. In order to develop students' speech, teachers will need to use methods and techniques that help students actively master the pronunciation, vocabulary, syntactic structure, and related speech of speech "[1]. Indeed, two aspects of the information presented draw our attention, firstly, that connected speech is inherently important in the development of the child's imagination, and secondly, the connection, the relationship, between the environment in which he is brought up and the family. Especially when the child is alone at home, following his wishes, watching TV, playing with toys, drawing. This means that in the process of developing speech skills, the parent must also pay attention to what the child is doing, paying constant and optimal attention to the child. For example, communication, family environment, lively care, attention requires the involvement of effective means that quickly affect the child's outlook in the first place.

In schools today, the involvement of technical means in a teacher's live communication speech helps to achieve the intended goal. Regular communication between the teacher and the class is also important in developing their oral speech. At this point, the speaker often uses a simple type of words, thereby sharpening the child's worldview. Repeated gradation, rhetoric and irony in oral speech, the methods of comparison, also make it necessary to make extensive use of different semantic transitions.

Memorization of poetic texts also plays an important role in grades 5-6 of Karakalpak. As an adult learner learns his or her mother tongue, he or she uses comparative imagery in teaching another language. These will be effective if done in the following way:

- First, the poetic text expresses emotional feelings;

- Secondly, it creates a basis for re-perception of the word and its layers of meaning; 
- Third, teamwork often leads to specific answers to questions that are not understood;

- Fourth, the formation of speaking skills is a result of the teacher's planned communication.

This means that the teacher must read the poetic text expressively. It reaches the reader orally. During the admission process, the student learns certain words, as well as helps him to express his personal attitude, to acquire the skills of free speech.

For example, we refer to the poetic text:

Jahonki muqaddas neni ko'ribdi,

Bariga onasan, ey qodir hayot.

Besh yuz yil naridan boqib turibdi,

Nurli bu yuzlarga Nuroniy bir zot.

Shu buyuk o'g'lingni ardoqlab dildan, -

Xalqim, ta'zim etsang arzigay tamom.

Uning nomi bilan birga bitilgan,

Dunyo daftariga o'zbek degan nom [2].

Translation:

What the saint of the world saw,

You are the mother of all, $\mathrm{O}$ mighty life.

Five hundred years from now,

$\mathrm{He}$ is the Enlightened One.

Sincerely yours,

My people, if you bow down, it's worth it.

Written with his name,

The word Uzbek is in the world book.

The poetic text serves as the primary basis for the formation of connected speech. The integrity of meaningful, emotionally perceived reality and experience encourages the reader not only to imagine, but to think deeply. The reader can understand in one reading that the name of Alisher Navoi is a great genius in the world. It is not difficult to feel the breath of time in these bytes presented in the form of information. After all, the worldview between history and the future creates the basis for the deepening of philosophical and aesthetic observation in the reader.

There are many visual aids for developing students' speech in the natural sciences taught in Karakalpak classrooms. In particular, the color and image products associated with the Aral Sea tragedy not only shape children's views of nature in the minds of students, but also allow them to become active connoisseurs of this process, to deepen their inner interests. They divide the objects they see during the excursion into groups with the help of the teacher's commentary, sorting and synthesizing and analyzing them. Such an approach not only warns of the harmful effects of ecophobia, but also reminds 
them of the soil in which they live, and encourages them to become engineers in the future to deal with such disasters.

Students 'speech cannot be imagined in isolation from their thinking. Speech is formed and improved on the basis of thinking. This is a phenomenon tested in pedagogical practice. The ability of Karakalpak students to speak, write and communicate fluently and fluently in Uzbek depends on the teacher's systematic approach to the issue.

Communication is a product of the human spiritual world. Communication is an important foundation of human society. Without it, no creative quality emerges. The student realizes to what extent he or she is mastering the problem with his or her pronunciation and evaluates him or herself. Uzbek language lessons effectively help to enrich children's speech, vocabulary, teach them to compose speech.

\section{Conclusion}

In general, in schools where the language of instruction is Karakalpak, responsibility and perseverance are required from the teacher to organize the connected speech of the students in an orderly manner. After all, good knowledge of speaking skills, mastery, innovations in the field, and instructions of a pedagogical nature also gives good results. After all, mental and emotional activity is two complementary human traits. It reflects a person's experience, character, and culture of behavior. There is no doubt that all the elements, issues of a recommendatory nature, have a real essence and serve to increase the effectiveness of the principles of reform.

\section{References}

[1]. Ahmadjanova M., Mamatqulova D. The system of developing oral and written speech of primary school students.// Young scientist №4. Scientific journal. International conference.

[2]. Oripov A. (1999) Selected works. Selection, Vol. - Tashkent. Publishing House of Literature and Art. - p. 56.

[3]. Aminova M.N., Majidova M. (2010) Education (encyclopedia for parents and coaches) - Tashkent. National Encyclopedia of Uzbekistan.

[4]. Issues of formation of speech culture in the educational process. Proceedings of the 5th regular conference in the Uzbek language. - Tashkent. "Sharq", 199.

[5]. Gulomov A., Qobilov B. (1995) Speech development classes. - Tashkent. "Okituvchi". [6]. Doniyorov, A. K., \& Karimov, N. R. (2020). An Incomparable Book of a Great Scholar. Bulletin Social-Economic and Humanitarian Research, (6), 63-71. 